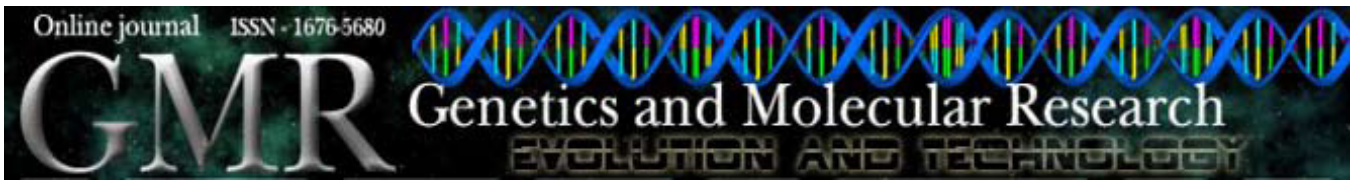

\title{
Vegetative compatibility and genetic analysis of Colletotrichum lindemuthianum isolates from Brazil
}

\author{
Q.L. Barcelos ${ }^{1}$, E.A. Souza ${ }^{2}$ and K.J. Damasceno e Silva ${ }^{3}$ \\ ${ }^{1}$ Departamento de Biologia, Universidade Federal de Lavras, \\ Lavras, MG, Brasil \\ ${ }^{2}$ Departamento de Biologia, Universidade Federal de Lavras, \\ Lavras, MG, Brasil \\ ${ }^{3}$ Embrapa Meio-Norte, Teresina, PI, Brasil \\ Corresponding author: E.A. Souza \\ E-mail: easouza@dbi.ufla.br
}

Genet. Mol. Res. 10 (1): 230-242 (2011)

Received June 9, 2010

Accepted November 11, 2010

Published February 15, 2011

DOI 10.4238/vol10-1gmr907

\begin{abstract}
The causal agent of common bean anthracnose, Colletotrichum lindemuthianum, has considerable genetic and pathogenic variability, which makes the development of resistant cultivars difficult. We examined variability within and between Brazilian pathotypes of $C$. lindemuthianum through the identification of vegetative compatibility groups (VCGs) and by RAPD analysis. Two hundred and ninety-five nit mutants were obtained from 47 isolates of various pathotypes of the fungus collected from different regions, host cultivars and years. In complementation tests, 45 VCGs were identified. Eighteen RAPD primers were employed in the molecular analyses, producing 111 polymorphic bands. Estimates of genetic similarities, determined from the Sorence-Dice coefficient, ranged from 0.42 to 0.97 ; the dendrogram obtained by cluster analysis revealed 18 groups of isolates.
\end{abstract}


RAPD and VCG markers presented high genotypic diversity. The number of significant associations $(\mathrm{P}=0.05)$ between RAPD, VCG and pathogenicity markers ranged from 0 (VCG) to $80 \%$ (pathogenicity). The test of multilocus association $\left(\mathrm{r}_{d}\right)$ for RAPD markers was significantly different from zero $(\mathrm{P}<0.001)$, suggesting linkage disequilibrium. However, the results for VCG markers show the presence of recombination mechanisms. In conclusion, RAPD markers and VCGs were useful for detecting genetic variability among isolates of $C$. lindemuthianum. We found considerable diversity among isolates from the same geographic origin within a short interval; this suggests rapid evolution. There is a need for further studies to elucidate the population structure of this pathogen in agro-ecosystems.

Key words: Anthracnose; Common bean; RAPD analysis; Vegetative compatibility group; nit mutants

\section{INTRODUCTION}

The causal agent of anthracnose, one of the most devastating diseases of the common bean (Phaseolus vulgaris), is the phytopathogen Colletotrichum lindemuthianum. Under suitable environmental conditions, this fungus can cause dramatic losses in crop production. Brazil is the largest producer of dry beans in the world; anthracnose is controlled in this country mainly by cropping cultivars that are genetically resistant to this phytopathogen (Damasceno e Silva et al., 2007). However, durable long-term resistance in $P$. vulgaris has not been achieved so far due to the high diversity in the C. lindemuthianum population.

Diversity in the phytopathogen has been demonstrated mainly through the identification of numerous pathotypes, using the binary race classification system proposed by the Centro Internacional de Agricultura Tropical (CIAT, 1990), and by application of molecular (Ansari et al., 2004; Mahuku and Riascos, 2004; Talamini et al., 2006; Damasceno e Silva et al., 2007) and morphological (Souza et al., 2007) markers. Mahuku and Riascos (2004) identified 90 different $C$. lindemuthianum pathotypes amongst 200 isolates originating from Andean and Mesoamerican countries, although pathogenicity and molecular analyses revealed no association between the isolates and the genomes of the host cultivars. A group of 30 pathotypes was identified in cultivar pathogenicity tests of 74 isolates of C. lindemuthianum collected from Central and South American, European and African countries (Ansari et al., 2004). Using amplified fragment length polymorphism analyses, these authors demonstrated an association between the genetic diversity of the fungal isolates and the country of origin, while no association was found between genetic group and pathotype classification.

Pathogenicity studies conducted in Brazil have resulted in the identification of more than 50 pathotypes of $C$. lindemuthianum, the most common of which are 65, 73 and 81 (Rava et al., 1994; Balardin et al., 1997; Sartorato, 2002; Talamini et al., 2006; Damasceno e Silva et al., 2007). Randomly amplified polymorphic DNA (RAPD) analyses 
revealed that intra-regional molecular diversity amongst these pathotypes is greater than inter-regional variability (Talamini et al., 2006; Damasceno e Silva et al., 2007).

An alternative technique for studying genetic diversity in populations of $C$. lindemuthianum involves the identification of vegetative compatible groups (VCGs) during the asexual reproductive phase of the fungus, since such groups can exchange genetic information via heterokaryosis (Brooker et al., 1991). Hyphae that are capable of anastomosis to form stable heterokaryons are considered to be vegetatively compatible; thus, isolates that form heterokaryons are often included in the same VCG (Leslie and Summerell, 2006).

In order to characterize and classify fungal isolates according to VCGs, it is necessary to develop mutant strains that are both resistant to chlorate and unable to use nitrate as the sole source of nitrogen, the so-called "nitrate non-utilising" or nit mutants. The characterization of VCGs has been employed successfully in various species of Colletotrichum (Brooker et al., 1991; Skroch et al., 1992; Wasilwa et al., 1993; Correll et al., 1993; Chacko et al., 1994; Beynon et al., 1995; Gichuru et al., 2000; Nitzan et al., 2002; Varzea et al., 2002; Abang et al., 2004; Pereira, 2005), and nitrate non-utilizing mutants have been used to demonstrate heterokaryosis and parasexual segregation in $C$. lindemuthianum isolates (Castro-Prado et al., 2007). However, little could be inferred about vegetative compatibility in this species, because the nit mutants were obtained from only five isolates. Therefore, there are no reports concerning the application of such mutants in the classification of populations of $C$. lindemuthianum.

Anastomosis formation among hyphae of different isolates of $C$. lindemuthianum has been evaluated (Rodríguez-Guerra et al., 2003; Ishikawa et al., 2008), allowing classification into several anastomosis groups. Anastomosis is, however, only the first step in the formation of a heterokaryon, since heterokaryotic cells formed by the fusion of isolates that are not in the same vegetative compatibility group either grow at a very much reduced rate or undergo apoptosis and cell death. The vegetative compatibility group status of an isolate depends on a number of genes, known as vic genes, involved in vegetative incompatibility control. Detailed information concerning vegetative compatibility group could be obtained by complementation with auxotrophic nit mutants, a technique that can provide unambiguous proof of compatibility.

We classified C. lindemuthianum isolates into distinct VCGs in order to determine the association between the various groups and pathogenicity, and examined the genetic similarities of the isolates by using RAPD markers.

\section{MATERIAL AND METHODS}

\section{Origin of $C$. lindemuthianum isolates}

Forty-seven C. lindemuthianum isolates belonging to 13 different pathotypes were collected from naturally infected bean cultivars produced in various regions of Brazil from 2000 to 2006 (Table 1). Small sections of infected plant tissue (leaves, stems and pods) were surface-sterilized, placed onto Petri dishes ( $90 \mathrm{~mm}$ in diameter) containing M3 culture medium (Junqueira et al., 1984) and incubated in the dark at $22^{\circ} \mathrm{C}$. Each isolate was purified using the single-spore isolation technique. 
Table 1. Descriptions of the isolates of Colletotrichum lindemuthianum.

\begin{tabular}{|c|c|c|c|c|c|c|c|c|c|}
\hline & Isolate & Pathotype & Origin & Year & & Isolate & Pathotype & Origin & Year \\
\hline 1 & LV5 & 81 & Lavras (MG) & - & 25 & LV67 & 321 & Pinhão (PR) & 2004 \\
\hline 2 & LV11 & 81 & Viçosa (MG) & 2001 & 26 & LV68 & 81 & Lavras (MG) & 2004 \\
\hline 3 & LV13 & 81 & Viçosa (MG) & 2001 & 27 & LV69 & 81 & Lambari (MG) & 2004 \\
\hline 4 & LV17 & 81 & Viçosa (MG) & 2001 & 28 & LV70 & 81 & Viçosa (MG) & 2003 \\
\hline 5 & LV18 & 87 & - & - & 29 & LV72 & 81 & Lambari (MG) & 2004 \\
\hline 6 & LV24 & 64 & - & - & 30 & LV73 & 65 & Ijaci (MG) & 2004 \\
\hline 7 & LV28 & 65 & Lavras (MG) & 2001 & 31 & LV75 & 81 & Heliodora (MG) & 2003 \\
\hline 8 & LV29 & 65 & Lavras (MG) & 2001 & 32 & LV76 & 73 & Lavras (MG) & - \\
\hline 9 & LV32 & 73 & - & 2002 & 33 & LV77 & 81 & Lavras (MG) & - \\
\hline 10 & LV33 & 337 & Viçosa (MG) & 2002 & 34 & LV80 & 65 & Lavras (MG) & 2004 \\
\hline 11 & LV43 & 81 & - & 2002 & 35 & LV84 & 73 & Lavras (MG) & - \\
\hline 12 & LV44 & 81 & - & 2002 & 36 & LV86 & 337 & Lavras (MG) & 2005 \\
\hline 13 & LV46 & 81 & Lambari (MG) & 2002 & 37 & LV88 & 337 & Lavras (MG) & 2005 \\
\hline 14 & LV48 & 65 & Coromandel (MG) & 2002 & 38 & LV89 & 65 & Lambari (MG) & 2005 \\
\hline 15 & LV49 & 81 & - & - & 39 & LV90 & 65 & Ijaci (MG) & 2005 \\
\hline 16 & LV50 & 72 & Lavras (MG) & - & 40 & LV94 & 65 & Lambari (MG) & 2005 \\
\hline 17 & LV51 & 73 & Lavras (MG) & 2004 & 41 & LV95 & 81 & Guarapuava (PR) & 2006 \\
\hline 18 & LV54 & 81 & Lambari (MG) & 2004 & 42 & LV96 & 71 & Campinas (SP) & 2006 \\
\hline 19 & LV55 & 65 & Ijaci (MG) & 2004 & 43 & LV97 & 64 & Campinas (SP) & 2006 \\
\hline 20 & LV57 & 65 & Lambari (MG) & 2004 & 44 & LV99 & 73 & Lambari (MG) & 2006 \\
\hline 21 & LV58 & 65 & Nepomuceno (MG) & 2004 & 45 & LV100 & - & Campinas (SP) & 2006 \\
\hline 22 & LV59 & 65 & Ijaci (MG) & 2004 & 46 & LV101 & 8 & Turvo (PR) & 2006 \\
\hline 23 & LV61 & 65 & Ijaci (MG) & 2004 & 47 & CL837* & 65 & Buritis (MG) & 2000 \\
\hline 24 & LV66 & 89 & - & - & & & & & \\
\hline
\end{tabular}

*Provided by EMBRAPA Arroz e Feijão (State of Goiás, Brazil); $(-)=$ information not available; $\mathrm{MG}=$ Minas Gerais; PR = Paraná; SP = São Paulo (States of Brazil).

\section{Isolation and characterisation of nit mutants}

The methods described by Brooker et al. (1991) were applied to the development of nit mutants. Briefly, mycelial plugs $(3 \mathrm{~mm}$ in diameter) were removed from the edges of the colonies and transferred to Petri dishes $(60 \mathrm{~mm}$ in diameter) containing minimal medium (MM) supplemented with potassium chlorate at concentrations of 15,20 or $25 \mathrm{~g} / \mathrm{L}$, with L-asparagine $(1.6 \mathrm{~g} / \mathrm{L})$ or L-threonine $(1.4 \mathrm{~g} / \mathrm{L})($ Klittich and Leslie, 1989). For each isolate, 10 mycelial plugs were incubated under the conditions described above and the colonies were examined weekly in order to detect formation of dense sectors. Such sectors were transferred to basal medium (BM) supplemented with sodium nitrate at a concentration of $2 \mathrm{~g} / \mathrm{L}$. Isolates presenting poor mycelial growth on this medium were considered to be nit mutants, while isolates presenting robust growth, similar to that of the wild-type cultures grown on $\mathrm{MM}+$ chlorate, were discarded (Leslie and Summerell, 2006).

Following identification, the nit mutants were transferred to Petri dishes containing BM separately supplemented with the nitrogen sources ammonium tartrate $(1.0 \mathrm{~g} / \mathrm{L})$, sodium nitrite $(0.5$ or $0.4 \mathrm{~g} / \mathrm{L})$ or hypoxanthine $(0.5 \mathrm{~g} / \mathrm{L})$. Plates were incubated under the conditions described above for seven days and mutants were characterized phenotypi- 
cally and classified as nit1, nit2, nit3, or nitM according to their growth parameters. BM media containing ammonium or nitrate salts were used as positive and negative controls, respectively (Leslie and Summerell, 2006).

\section{Vegetative complementation tests}

The vegetative self-compatibilities of different nit mutants of a single isolate and the cross-compatibilities between nit mutants of different isolates were tested by pairing mycelium plugs in order to determine the capacity for anastomosis (Leslie and Summerell, 2006). Forty-six isolates produced nit 3 mutants; these were paired against a nit 1 mutant from each of the seven isolates that produced both nit 1 and nit 3 mutants and also against the nitM mutant derived from the remaining isolate. A mycelial plug of a nit1 (or nitM) mutant was placed at the center of a Petri dish $(90 \mathrm{~mm}$ in diameter) containing $\mathrm{BM}+\mathrm{ni}$ trate, and four mycelial plugs of nit 3 mutants were arranged around the edge of the dish at a distance of $1 \mathrm{~cm}$ from the central plug. Each combination of mutants was repeated twice, and the dishes were incubated under the conditions described above for at least four weeks. Growth of aerial mycelia in the contact zone between the two colonies and formation of heterokaryons were monitored weekly. Paired isolates that exhibited dense aerial mycelia at the intersection between colonies of nit3 and nit1 (or nitM) mutants of the other isolate were included in the same VCG, while paired isolates that exhibited sparse growth at these intersections were included in different VCGs. Positive controls presented robust growth of aerial mycelia at the intersection between nit3 and nit1 (or nitM).

\section{DNA extraction and RAPD analysis}

Mycelia from each of the 47 isolates were placed onto Petri dishes containing M3 medium (Junqueira et al., 1984) and incubated as described above for 12 days. Agar plugs taken from the actively growing margins of the colonies were transferred to Erlenmeyer flasks containing $125 \mathrm{~mL} \mathrm{M3} \mathrm{liquid} \mathrm{medium} \mathrm{and} \mathrm{incubated} \mathrm{for} \mathrm{seven} \mathrm{days} \mathrm{under} \mathrm{constant}$ agitation $(110 \mathrm{rpm})$ in the dark at $20^{\circ} \mathrm{C}$. The mycelial mass was filtered through cheesecloth, washed with $0.05 \mathrm{M}$ EDTA, and stored at $-20^{\circ} \mathrm{C}$ until required. DNA was extracted from the isolates according to a modified version of the method of Raeder and Broda (1985), except for seven isolates that failed to grow in liquid medium and could not be included in the analyses.

RAPD reactions were carried out using 17 arbitrary primers (Table 2; Operon Technologies, Alameda, CA, USA). Amplification reactions were performed using an Eppendorf (Hamburg, Germany) MasterCycler Gradient 5331 in a total volume of $12 \mu \mathrm{L}$ containing $4.49 \mu \mathrm{L}$ water, $25 \mathrm{ng}$ genomic DNA, $50 \mu \mathrm{M}$ of each dNTP, $0.4 \mu \mathrm{M}$ of each oligonucleotide primer, $50 \mathrm{mM}$ Tris- $\mathrm{HCl}, \mathrm{pH} 8.0,2.0 \mathrm{mM} \mathrm{MgCl}, 20 \mathrm{mM} \mathrm{KCl}$ and 0.4 units Taq DNA polymerase. The amplification program consisted of one initial denaturation cycle of $2 \mathrm{~min}$ at $94^{\circ} \mathrm{C}$, followed by 40 cycles of $2 \mathrm{~min}$ at $94^{\circ} \mathrm{C}, 15 \mathrm{~s}$ at $37^{\circ} \mathrm{C}$ and $1 \mathrm{~min}$ at $72^{\circ} \mathrm{C}$, and a final extension step of $2 \mathrm{~min}$ at $72^{\circ} \mathrm{C}$. Amplicons were separated by electrophoresis on $1 \%$ agarose gels, bands were visualized under UV light using a Fotodyne (New Berlin, WI, USA) ultraviolet trans-illuminator and photographed with an Eastman Kodak (Rochester, NY, USA) EDA -290 camera. 
Table 2. Primers used in RAPD analysis (Operon Technologies, Alameda, CA, USA).

\begin{tabular}{llll}
\hline Primers & Sequences & Primers & Sequences \\
\hline OPAQ12 & 5'CAGCTCCTGT3' & OPAS15 & 5'CTGCAATGGG3' \\
OPAR06 & 5'TGGGGCTCAA3' & OPAS17 & 5'AGTTCCGCGA3' \\
OPAR12 & 5'GGATCGTCGG3' & OPAS18 & 5'GTTGCGCAGT3' \\
OPAS03 & OPAT08 & 5'TCCTCGTGGG3' \\
OPAS06 & 5'GGGTTCCAAC3' & OPBB07 & 5'GAAGGCTGGG3' \\
OPAS08 & 5'GCGCGTAAG3' & OPBB09 & 5'AGGCCGGTCA3' \\
OPAS10 & OPGBCTGCAGT3' & 5''ACTTGCCTGG3' \\
OPAS12 & 5'CCCGTCTACC3' & OPBB16 & 5'TCGGCACCGT3' \\
OPAS14 & 5'TGACCAGGCA3' & & \\
\hline
\end{tabular}

Location within the manuscript: Material and Methods, subsection "DNA extraction and RAPD analysis".

\section{Data analysis}

Each individual isolate was scored according to the presence (1) or absence (0) of DNA amplicons; only polymorphic bands were considered. The genetic similarity between isolates $i$ and $j\left(s g_{i j}\right)$ was estimated from the Sorensen-Dice coefficient as given by the expression $s g_{i j}=$ $2 a /(2 a+b+c)$, where $a$ represents the presence of a determined band in $i$ and $j, b$ represents the presence of the band in $i$ and the absence in $j$, and $c$ represents the absence of the band in $i$ and the presence in $j$. A dendrogram was produced from the similarity matrix thus generated, using the unweighted pair-group method with arithmetic means (UPGMA) with the assistance of the NTSYS-PC 2.1 software (Rohlf, 2000). The errors associated with each similarity were estimated according to the following expression modified from Skroch et al. (1992):

$$
\text { estimated standard error }\left(s_{s g}\right)=\sqrt{s g_{i j} \frac{1-s g_{i j}}{n-1}}
$$

(Equation 1)

where $n$ is the sum of $a, b$ and $c$ for each isolate pair. Genetically different isolates were identified in the dendrogram on the basis of the estimated maximum significant similarity value $\left(s g_{m}\right)$, which was determined from:

$$
s g_{m}=1-\left(t \times \bar{s}_{\mathrm{sg}}\right)
$$

(Equation 2)

where $t$ is the tabulated value of the Student $t$ distribution at the $1 \%$ level of probability with $n-2$ degrees of freedom, and $\bar{s}_{s g}$ is the mean error of the comparisons considered in the dendrogram.

The exact test of digenic linkage disequilibrium for haploid data, which is an extension of the Fisher exact test for contingency tables (Slatkin, 1994), was applied using the Arlequin software version 2.0 (Schneider et al., 1997). RAPD locus, VCG and pathogenicity were used to test the genetic differentiation for each nonrandom association among pairs of these different markers. A pathotype was identified as a combination of virulence factors of a strain on the set of 12 differentials.

The MULTILOCUS software V2.1 (2003) was used to investigate multilocus linkage disequilibrium. The index of association $\left(\mathrm{I}_{A}\right)$ (Brown et al., 1980; Smith et al., 1993), which tests the importance of clonal or sexual reproduction within each population, was calculated. The $\mathrm{I}_{A}$ is calculated by measuring the distances between all pairs of loci, and comparing them 
to the expected value (zero), assuming no linkage disequilibrium. Unfortunately $\mathrm{I}_{A}$ is sensitive to the number of loci sampled, hence we also used the linkage disequilibrium measure $\left(r_{d}\right)$ developed by Agapow and Burt (2001), which is independent of the number of loci sampled, and the significance of which is also tested by its deviation from the expected value (zero), assuming no linkage disequilibrium. The $\mathrm{r}_{d}$ value was calculated and 1000 randomizations were performed. RAPD haplotypes were used for multilocus analysis and a haplotype was defined as a combination of RAPD alleles at all polymorphic loci.

\section{RESULTS}

\section{Generation of nit mutants}

A number of isolates of $C$. lindemuthianum formed dense sectors when cultivated on $\mathrm{MM}+$ chlorate, although the frequency of formation varied between isolates, with some presenting a single sector per colony and others forming two or more sectors per colony (Figure 1). Sectors could be observed after three weeks in culture, although most emerged only after five to six weeks of incubation. The frequency of formation of chlorate-resistant mutants was greater in MM supplemented with $20 \mathrm{~g} / \mathrm{L}$ than with $15 \mathrm{~g} / \mathrm{L}$ potassium chlorate, while a concentration of $25 \mathrm{~g} / \mathrm{L}$ of the salt was highly toxic for some isolates and completely inhibited the growth of mycelia. Chlorate-resistant mutants were transferred to BM + nitrate, and those that presented poor mycelial growth were considered to be nit mutants.

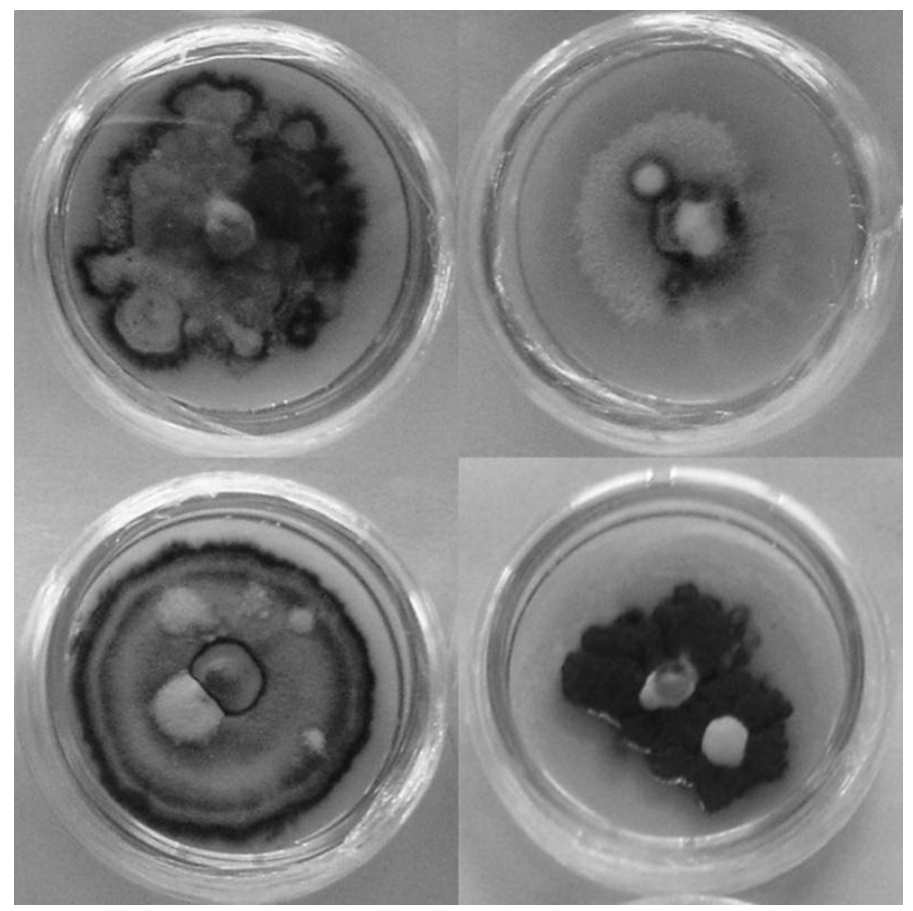

Figure 1. Formation of chlorate-resistant sectors in Colletotrichum lindemuthianum cultured on minimal medium containing potassium chlorate. 
The 295 nit mutants recovered from the 47 C. lindemuthianum isolates were incubated separately on selective medium (BM + tartrate, nitrite or hypoxanthine), and 279 nit3 mutants were identified, together with 15 nit 1 mutants and one nit $M$ mutant. Seven of the 47 isolates of $C$. lindemuthianum produced nit 1 and nit 3 mutants, 39 isolates produced only nit 3 mutants and one isolate produced a single nitM mutant. A large number of mutants were initially classified as nit 3 when $\mathrm{BM}+0.5$ $\mathrm{g} / \mathrm{L}$ sodium nitrite was employed as the selective medium, but when the concentration of the salt was reduced to $0.4 \mathrm{~g} / \mathrm{L}$, four nit 3 mutants changed phenotype to nit 1 . Supplementation of MM + chlorate with the amino acid L-threonine did not significantly increase the number of nit $M$ mutants formed.

\section{Vegetative compatibility}

Six of the 47 C. lindemuthianum isolates were observed to be self-incompatible since the development of aerial mycelia and the formation of heterokaryons were not observed at the line of intersection between colonies of nit 3 and nit 1 mutants derived from the same isolate. One isolate (LV97), however, exhibited weak self-compatibility, as shown by the sparse mycelium growth at the intersection between nit mutants.

The results of cross-compatibility tests allowed classification of the C. lindemuthianum population into 45 separate VCGs, among which three isolates (LV13, LV68 and LV48) were grouped into one VCG, while the other isolates were incompatible and constituted 44 different VCGs. A strong cross-complementation was observed between nit 3 mutants derived from isolates LV13 (C) and LV68 (D) (Figure 2). The dense line of growth corresponds to the formation of heterokaryons. In contrast, only weak complementation was observed between the isolate pairs LV70/LV51, LV68/LV51 and LV97/LV73, hence each isolate was classified in a separate VCG. For most of the complementing isolates, the formation of heterokaryons could be observed only after the second week of incubation, but in the case of isolates LV13 and LV68, heterokaryons appeared within the first week. No complementation was observed between nit 3 and nitM mutants.

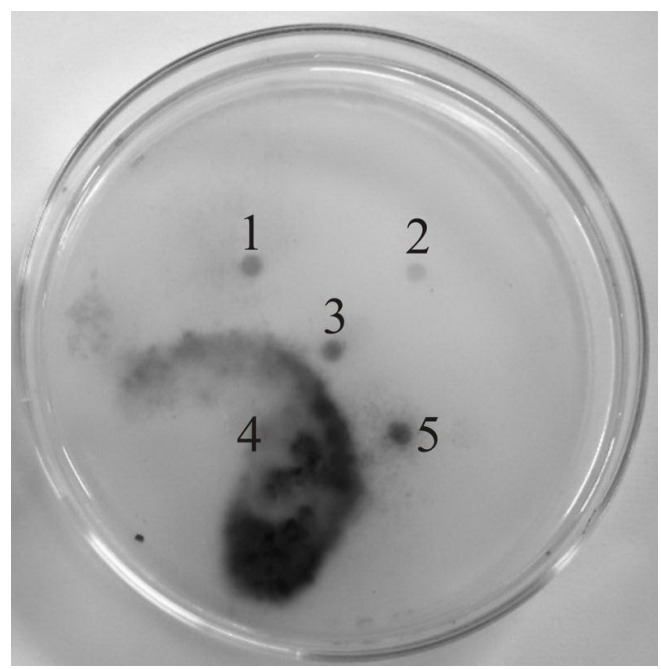

Figure 2. Compatibility assays between nit mutants: the mycelial plug $(3)$ at the center of the plate is a nit 1 mutant from isolate LV48 (1) and the four nit3 mutants on the periphery of the plate are from isolates LV48 (1), LV69 (2), LV13 (4), and LV68 (5). The dense line of growth corresponds to the formation of heterokaryons. 


\section{Genetic similarity}

In order to establish genetic similarities between isolates of $C$. lindemuthianum through the analysis of RAPD markers, 111 polymorphic bands were analyzed; an average of 6.2 bands were generated by each primer. The coefficients of genetic similarity within the fungal population varied between 0.42 and 0.96 , with a cut-off point of 0.889 (Figure 3). Based on the dendrogram, the C. lindemuthianum population could be grouped into 18 genetically similar clusters. Some associations were observed between pathogenicity, RAPD groups and geographic origin. Group II (Figure 3), including isolates LV44, LV49 and LV77, belongs to pathotype 81. Isolates LV17 and LV70, which also belong to pathotype 81, were collected in the same geographic region and were grouped together (group III, Figure 3). Both isolates from group XI (LV32 and LV51) and group XII (LV76 and LV84) belong to pathotype 73 and were collected in Lavras, MG. An association was observed between RAPD groups and VCG, when the isolates LV13 and LV48 were grouped together according to genetic similarity; they were also included in the same VCG. Additionally, isolates LV28, LV29, LV80, LV89, LV90, LV95, LV54, LV59, LV61, LV50, and LV43 were classified in separate genetic groups and in distinct VCGs; most of these isolates belong to pathotype 65 , showing intra-specific genetic variation.

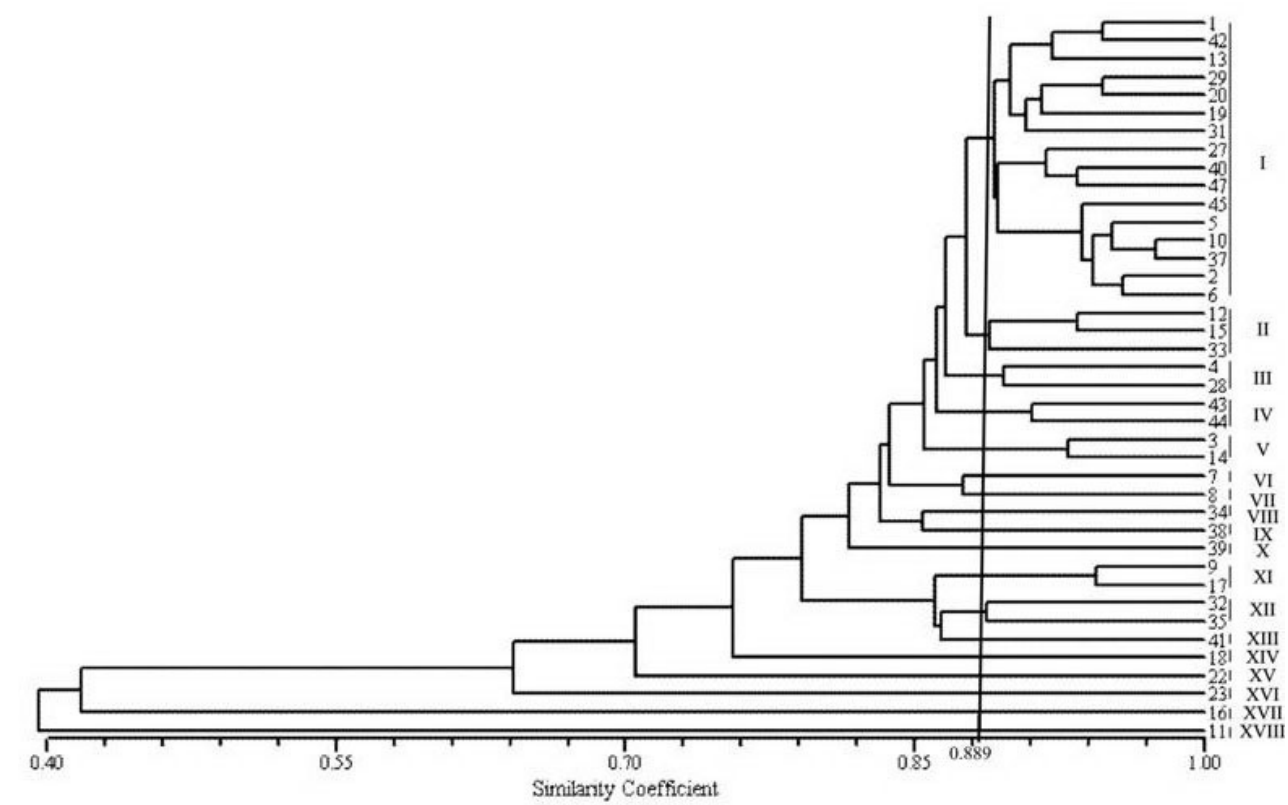

Figure 3. UPGMA analysis of population data showing the relationship between the 40 isolates of Colletotrichum lindemuthianum.

\section{Linkage disequilibrium}

The number of polymorphic loci scored was 101 for the RAPD markers, six for pathogenicity markers and 39 for VCG markers. The number of significant $(P=0.05)$ associations between RAPD, VCG and pathogenicity markers ranged from 0 (VCG) to $80 \%$ (pathogenicity) 
(Table 3). All multilocus genotypes occurred only once. The multilocus association $\left(\mathrm{I}_{A}\right.$ and $\mathrm{r}_{d}$ ) for RAPD markers was significantly different from zero $(\mathrm{P}<0.001)$, confirming that there is linkage disequilibrium in this population. The $\mathrm{I}_{A}$ and $\mathrm{r}_{d}$ values observed were 10.71 and 0.10 , respectively.

Table 3. Number and percentage of significant nonrandom associations between pairs of random-amplified
polymorphic DNA(RADP), pathogenicity and vegetative compatibility group (VCG) markers in Colletotrichum
lindemuthianum.
\begin{tabular}{lccc}
\hline Marker & $\mathrm{N}^{\circ}$ of significant/No. of calculated combinations & VCG \\
\cline { 2 - 4 } & $\mathrm{RAPD}$ & Pathogenicity & \\
\hline RAPD & $3020 / 5050(60 \%)$ & $164 / 606(27 \%)$ & $946 / 3838(25 \%)$ \\
Pathogenicity & - & $12 / 15(80 \%)$ & $148 / 228(65 \%)$ \\
VCG & - & - & $0 / 703(0 \%)$ \\
\hline aP $<0.05$. & &
\end{tabular}

\section{DISCUSSION}

The high frequency of nit 3 mutant that we observed was also found in previous research on Colletotrichum species (Brooker et al., 1991; Beynon et al., 1995), although some studies reported a predominance of nit1 mutants (Nitzan et al., 2002; Pereira, 2005; Fávaro et al., 2007). The recovery of nit phenotypes (especially nitM) from Colletotrichum species is clearly not straightforward and sometimes is not possible (Beynon et al., 1995; Varzea et al., 2002).

Self-incompatible isolates were observed within the C. lindemuthianum population; this phenomenon had already been described for other Colletotrichum species (Brooker et al., 1991; Wasilwa et al., 1993; Beynon et al., 1995; Varzea et al., 2002; Pereira, 2005). Incompatibility between most of the $C$. lindemuthianum isolates may be explained on the basis of the observed self-incompatibility, since such isolates do not normally form heterokaryons with other isolates (Leslie, 1993). In Aspergillus flavus, Papa (1986) suggested that the lack of complementation observed between some isolates could be due to a double mutation in some of the nit mutants. Another explanation stated that the lack of complementation resulted from the inability of the isolates to form hyphal anastomoses (Correl et al., 1993), a deficiency also detected in $C$. lindemuthianum (Ishikawa et al., 2008). In the latter case, it was shown that some isolates of $C$. lindemuthianum (namely, LV58, LV61 and LV73) could be classified into the same anastomosis group, but they belonged to different groups based on the criterion of genetic similarity in RAPD analysis. Although these isolates were genetically different they had the ability to undergo anastomosis, which is the first step in the parasexual cycle. In our study, however, isolates LV58, LV61 and LV73 were included in different VCGs, suggesting that the alleles controlling pre-fusion events are similar, while the alleles controlling vegetative compatibility are different. Thus, although these isolates were able to form anastomoses, they could not form heterokaryons. Since isolate LV73 was self-incompatible, the alteration must have occurred in the het genes controlling self- and non-self recognition (Leslie and Summerell, 2006).

Although the sexual structures of $C$. lindemuthianum have not been found in nature (Mahuku and Riascos, 2004), the sexual form has been observed frequently in the laboratory, 
from lesions isolated from common bean fields in Brazil (Camargo Jr. et al., 2007; Damasceno e Silva et al., 2007). Moreover, the organization and genetic diversity of this species is more comparable with populations that are derived sexually than from asexual reproduction (Brygoo et al., 1998). If a sexual phase occurs, considerable genetic variability, together with the formation of various VCGs, may be expected, since the possible combinations between vic loci are numerous (Leslie, 1993).

In our study, RAPD markers and VCGs were useful for detecting high genetic variability among isolates of $C$. lindemuthianum. Defining the genetic structure of populations is a logical first step in studies of fungal population genetics because the genetic structure of a population reflects its evolutionary history and its potential to evolve (McDonald, 1997). The results demonstrate considerable diversity within isolates from the same geographic origin within a short time, and this suggests rapid evolution. Capelle and Neema (2005) showed local adaptation at the scale of the individual common bean plant and indicated that fine-scale dynamics has evolutionary consequences in this pathosystem. However, the origin of these patterns could involve weak dispersal ability of the spores, founder effects, greater evolutionary potential of the fungus, and/or selection pressure by the resistance genes of the host. Moreover, the common bean is grown during three seasons in Brazil; therefore, the pathogen populations evolve, adapting to constant changes in environmental conditions.

In our study, the digenic test for linkage disequilibrium showed a low to high percentage $(0-80 \%)$ of pair-wise comparisons in disequilibrium (Table 3$)$. The high level of linkage disequilibrium (80\%) for pathogenicity markers may be due to the large number of isolates belonging to the same pathotype and the small number of different pathotypes. Moreover, this trait is under selection mainly by host-resistant genes, which leads to linkage disequilibrium. VCG markers showed lack of linkage disequilibrium $(0 \%)$, and this suggests that recombination is occurring. RAPD markers showed high level of linkage disequilibrium $(60 \%)$. However, the $r_{d}$ value was low (considering an $r_{d}$ value of $1.0=$ clonal, and $0=$ no linkage) confirming that it is possible that a level of recombination occurs in this pathogen. Actually, there is evidence of asexual recombination through conidial anastomosis tube fusion (Roca et al., 2004) and of the parasexual cycle (Castro-Prado et al., 2007) in C. lindemuthianum. Moreover, there are reports of sexual reproduction in this pathogen in Brazil (Damasceno e Silva et al., 2007; Camargo Jr. et al., 2007; Souza et al., 2007). There are some hypotheses that try to explain this high level of linkage disequilibrium. RAPD is a selectively neutral marker, and a sporadic sexual cycle followed by several generations of asexual reproduction would lead to the linkage disequilibrium. Another explanation could be a reminiscent linkage disequilibrium caused by a founder effect because the main inoculum source of $C$. lindemuthianum is seedborn contamination; also, there is weak dispersal ability of the spores in the field.

The level and distribution of genetic variability within and between populations of plant pathogens provide an indication of the adaptability of a pathogen in overcoming the effects of artificial and natural stresses on the population. Such genetic changes can neutralize the measures employed to control the pathogen, such as application of fungicides and use of genetically resistant cultivars (McDonald et al., 1989; Adachi et al., 1993; McDonald and Linde, 2002). We affirm the difficulties incurred in achieving long-term resistance against anthracnose in the common bean and emphasize the need for studies to elucidate the population structure of this pathogen in agro-ecosystems. 


\section{ACKNOWLEDGMENTS}

The authors thank Dr. Maria Cristina Mendes-Costa of Centro Universitário de Lavras and CAPES, CNPq and FAPEMIG for making this study possible.

\section{REFERENCES}

Abang MM, Hoffmann P, Winter S, Green KR, et al. (2004). Vegetative compatibility among isolates of Colletotrichum gloeosporioides from Yam (Dioscorea spp.) in Nigeria. J. Phytopathol. 152: 21-27.

Adachi Y, Watanabe H, Tanabe K, Doke N, et al. (1993). Nuclear ribosomal DNA as a probe for genetic variability in the Japanese pear pathotype of Alternaria alternata. Appl. Environ. Microbiol. 59: 3197-3205.

Agapow PM and Burt A (2001). Indices of multilocus linkage disequilibrium. Mol. Ecol. Notes 1: 101-102.

Ansari KI, Palacios N, Araya C, Langin T, et al. (2004). Pathogenic and genetic variability among Colletotrichum lindemuthianum isolates of different geographic origins. Plant Pathol. 53: 635-642.

Balardin RS, Jarosz AM and Kelly JD (1997). Virulence and molecular diversity in Colletotrichum lindemuthianum from South, Central, and North America. Phytopathology 87: 1184-1191.

Beynon SM, Coddington A, Lewis BG and Varzea V (1995). Genetic variation in the coffee berry disease pathogen, Colletotrichum kahawae. Physiol. Mol. Plant Pathol. 46: 457-476.

Brooker NL, Leslie JF and Dickman MB (1991). Nitrate non-utilizing mutants of Colletotrichum and their use in studies of vegetative compatibility and genetic relatedness. Phytopathology 81: 672-677.

Brown AHD, Feldman MW and Nevo E (1980). Multilocus structure in natural populations of Hordeum spontaneum. Genetics 96: 523-536.

Brygoo Y, Caffier V, Carlier J, Fabre JV, et al. (1998). Reproduction and Population Structure in Phytopathogenic Fungi. In: Molecular Variability of Fungal Pathogens (Bridge P, Couteaudier Y and Clarkson J, eds.). CAB International, Wallingford, 133-148.

Camargo OA Jr, Souza EA, Mendes-Costa MC, Santos JB, et al. (2007). Identification of Glomerella cingulata f. sp phaseoli recombinants by RAPD markers. Genet. Mol. Res. 6: 607-615.

Capelle J and Neema C (2005). Local adaptation and population structure at a micro-geographical scale of a fungal parasite on its host plant. J. Evol. Biol. 18: 1445-1454.

Castro-Prado MA, Querol CB, Sant'Anna JR, Miyamoto CT, et al. (2007). Vegetative compatibility and parasexual segregation in Colletotrichum lindemuthianum, a fungal pathogen of the common bean. Genet. Mol. Res. 6: 634-642.

Chacko RJ, Weidemann GJ, Tebeest DO and Correll JC (1994). The use of vegetative compatibility heterokaryosis to determine potential asexual gene exchange in Colletotrichum gloeosporioides. Biol. Control 4: 382-389.

CIAT (1990). Informe Anual 1988: Programa de Frijol (Documento de Trabajo, 72). In: Centro Internacional de Agricultura Tropical, Cali, 128-129.

Correll JC, Morelock TE and Gerber JC (1993). Vegetative compatibility and virulence of the spinach anthracnose pathogen, Colletotrichum dematium. Plant Dis. 77: 668-691.

Damasceno e Silva KJ, Souza EA and Ishikawa FH (2007). Characterization of Colletotrichum lindemuthianum isolates from the State of Minas Gerais, Brazil. J. Phytopathol. 155: 241-247.

Fávaro LCL, Araújo WL, Souza-Paccola EA, Souza-Paccola EA, et al. (2007). Colletotrichum sublineolum genetic instability assessed by mutants resistant to chlorate. Mycol. Res. 111: 93-105.

Gichuru EK, Várzea VMP, Rodrigues Júnior CJ and Masaba DM (2000). Vegetative compatibility grouping of Colletotrichum kahawae in Kenya. J. Phytopathol. 148: 233-237.

Ishikawa FH, Souza EA and Davide LMC (2008). Genetic variability within isolates of Colletotrichum lindemuthianum belonging to race 65 from the State of Minas Gerais, Brazil. Biologia 63: 156-161.

Junqueira NTV, Chaves GM, Zambolin L, Romero R, et al. (1984). Isolamento, cultivo e esporulação de Microcylus ulei, agente etiológico do mal das folhas da seringueira. Ceres 31: 322-331.

Klittich CJR and Leslie JF (1989). Chlorate-resistant, nitrate-utilizing (crn) mutants of Fusarium moniliforme (Gibberella fujikuroi). J. Gen. Microbiol. 135: 721-727.

Leslie JF (1993). Fungal vegetative compatibility. Annu. Rev. Phytopathol. 31: 127-150.

Leslie J and Summerell BA (2006). Vegetative Compatibility Groups (VCGs). In: The Fusarium Laboratory Manual (Leslie JF and Summerell BA, eds.). Blackwell Publishing Ltd., Malden, 31-43.

Mahuku GS and Riascos JJ (2004). Virulence and molecular diversity within Colletotrichum lindemuthianum isolates from Andean and Mesoamerican bean varieties and regions. Eur. J. Plant Pathol. 110: 253-263. 
McDonald BA (1997). The population genetics of fungi: tools and techniques. Phytopathology 87: 448-453.

McDonald BA and Linde C (2002). Pathogen population genetics, evolutionary potential, and durable resistance. Annu. Rev. Phytopathol. 40: 349-379.

McDonald BA, McDermott JM, Goodwin SB and Allard RW (1989). The population biology of host-pathogen interactions. Annu. Rev. Phytopathol. 27: 77-94.

Nitzan N, Hazanovsky M, Tal M and Tsror LL (2002). Vegetative compatibility groups in Colletotrichum coccodes, the causal agent of black dot on potato. Phytopathology 92: 827-832.

Papa K (1986). Heterocaryon incompatibility in Aspergillus flavus. Mycologia 78: 98-101.

Pereira I (2005). Compatibilidade Vegetativa e Sexual do Complexo Glomerella-Colletotrichum Associado ao Cafeeiro e Estudos Histopatológicos. MSc. Dissertation, Universidade Federal de Lavras, Lavras.

Raeder U and Broda P (1985). Rapid preparation of DNA from filamentous fungi. Appl. Microbiol. 1: 17-20.

Rava CA, Purchio AF and Sartorato A (1994). Caracterização de patótipos de Colletotrichum lindemuthianum que ocorrem em algumas regiões produtoras de feijoeiro comum. Fitopatol. Bras. 19: 167-172.

Roca MG, Davide LC, Davide LM, Mendes-Costa MC, et al. (2004). Conidial anastomosis fusion between Colletotrichum spp. Mycol. Res. 108: 1320-1326.

Rodríguez-Guerra R, Ramírez-Rueda MT, Martínez O and Sompson J (2003). Variation in genotype, pathotype and anastomosis groups of Colletotrichum lindemuthianum isolates from Mexico. Plant Pathol. 52: 228-232.

Rohlf F (2000). Numerical Taxonomy and Multivariate Analysis System. Version 2.1. Exeter Software, New York.

Sartorato A (2002). Determinação da Variabilidade Patogênica do Fungo Colletotrichum lindemuthianum (Sacc) Scrib. In: VII Congresso Nacional de Pesquisa de Feijão, Resumos Setembro de 2002, Universidade de Viçosa, Viçosa, 114-116.

Schneider S, Kueffer JM, Roessli D and Excoffier L (1997). ARLEQUIN VER. 1.1: a Software for Population Genetic Data Analysis. Genetic and Biometry Laboratory, University of Geneva, Geneva.

Skroch P, Tivang J and Nienhuis J (1992). Analysis of Genetic Relationships Using RAPD Marker Data. In: Applications of RAPD Technology to Plant Breeding Crop Science Society of America, Minneapolis, 26-30.

Slatkin M (1994). Linkage disequilibrium in growing and stable populations. Genetics 137: 331-336.

Smith JM, Smith NH, O'Rourke M and Spratt BG (1993). How clonal are bacteria? Proc. Natl. Acad. Sci. U. S. A. 90 : 4384-4388.

Souza BO, Souza EA and Mendes-Costa MC (2007). Determination of variability in isolates of Colletotrichum lindemuthianum based on morphological and cultural markers. Ciênc. Agrotec. 31: 1000-1006.

Talamini V, Souza EA, Pozza EA, Silva GF, et al. (2006). Genetic divergence among and within Colletotrichum lindemuthianum races assessed by RAPD. Fitopatol. Bras. 31: 545-550.

Varzea VMP, Rodrigues CJ Jr and Lewis BG (2002). Distinguishing characteristics and vegetative compatibility of Colletotrichum kahawae in comparison with other related species from coffee. Plant Pathol. 51: 202-207.

Wasilwa WA, Correll JC, Moreclock T and McNew RE (1993). Re-examination of races of the cucurbit anthracnose pathogen, Colletotrichum orbiculare. Phytopathology 83: 1190-1198. 